\title{
Influence of diffusible hydrogen on brittle fracture resistibility of metal in heat-affected zone of high-strength carbon steel
}

\author{
Wpływ wodoru dyfundującego na odporność \\ na kruche pękanie w SWC \\ wysokowytrzymałej stali węglowej
}

\begin{abstract}
Influence of diffusible hydrogen on the change of brittle fracture resistibility and mode of HAZ metal of welded joints on high-strength steels with $0,58 \%$ and $0,65 \%$ carbon content has been studied. Methods of simulation of thermal cycle of welding, saturation of model samples by hydrogen and their subsequent testing at bending were used to determine the influence of diffusible hydrogen on stress intensity factor K1C of HAZ metal. Metal microstructure in HAZ overheated zone and model sample fractures after testing were studied. It is shown that high-strength carbon steels and their joints have high susceptibility to embrittlement in the presence of hydrogen. Metal structural condition plays an essential role here. Optimum structure of HAZ metal is bainiticmartensitic one at more than 1 ratio of structural components. At saturation of joints by diffusion hydrogen occurring in welding, their brittle fracture susceptibility increases. To lower metal embrittlement, it is necessary to apply special welding processes, at which hydrogen saturation of deposited metal is minimum (less than $0,2 \mathrm{ml} / 100 \mathrm{~g}$ ) or techniques, allowing removal of diffusible hydrogen from the metal after welding.
\end{abstract}

Keywords: brittle fracture, diffusible hydrogen, high-strength

\section{Streszczenie}

W artykule zaprezentowano wyniki badań poświęconych opisaniu wływu wodoru dyfundującego na kruche pękanie w SWC złączy spawanych wysokowytrzymałej stali o stężeniu masowym węgla $0.58 \%$ oraz $0,65 \%$. Do określenia współczynnika intensywności naprężeń KIC w SWC użyto metod symulacji cyklu termicznego spawania z możliwością nasycania wodorem SWC. Przebadano mikrostrukturę przełomów w obszarze przegrzania w SWC próbek z symulatora cykli cieplnych spawania. Otrzymane wyniki wskazują, że złącza spawane stali o wysokiej wytrzymałości wykazują wysoką skłonność do pęknięć wodorowych. Właściwości struktury materiału odgrywają pod tym względem znaczącą rolę. Za optymalną strukturę w SWC uznaną bainityczno-martenzytyczną. Nasycenie złączy wodorem znacząco zwiększa ich skłonność do kruchego pękania. W celu obniżenia kruchości metalu w SWC koniecznym jest stosowanie niskowodorowych procesów spawania, w których nasycenie wodorem jest poniżej $0,2 \mathrm{ml} / 100 \mathrm{~g}$ stopiwa lub technik pozwalających obniżenie stężenia wodoru po spawaniu w obszarze złącza.

Słowa kluczowe: pęknięcia wodorowe, stal wysokiej wytrzymałości

Alexandre Gaivoronskiy, Sergey Kasatkin, Cand. Sci. (Eng.), Lyudmila Markashova, Doctor Sci. (Eng.), Tatyana Zuber, Engineer - E.O.Paton Electric Welding Institute of the National Academy of Sciences of Ukraine, Kiev. 


\section{Introduction}

Hot cracking resistance of welded joints of structures and items, made from high-strength steels, depends on the degree of quenching of metal structure in the heat-affected zone (HAZ). It is also known that diffusible hydrogen, accumulating in structure discontinuities, increases the level of local inner stresses in the metal. This leads to further embrittlement of metal, its ductile properties abruptly decrease, and processes of crack initiation and propagation in the joints are intensified [1-3]. It is also established that hydrogen influence becomes stronger with increase of metal strength.

In arc welding and surfacing of high-strength steels, carbon content in which is $0.50 \%$ and higher, quenching martensitic-bainitic structures with higher dislocation density form in the HAZ overheated zone. Ultimate strength $\sigma \mathrm{T}$ of such metal is more than 1060 $\mathrm{MPa}$, and relative elongation $\delta 5$ is not higher $9.3 \%[4$, 5]. It is anticipated that in this case even small local hydrogen concentrations will lead to essential changes of brittle fracture resistibility of metal.

However, as weldability studies of high-strength steels with more than $0.50 \%$ carbon were started comparatively recently, experimental data on the influence of diffusible hydrogen content on brittle fracture of HAZ metal of welded joints are not available.

The objective of the work is determination of the influence of diffusible hydrogen content on brittle fracture of HAZ metal of high-strength steel welded joints, proceeding under static loading. The material used were high-strength carbon steels of the following compositions, wt.\%:

- $0.58 \mathrm{C} ; 0.44 \mathrm{Si} ; 0.77 \mathrm{Mn} ; 0.10 \mathrm{Ni}, 0.05 \mathrm{Cr} ; 0.012 \mathrm{~S}$;

$0.011 \mathrm{P}$ (wheel steel of grade $2[6]$ );

- 0.65 C; $0.19 \mathrm{Si} ; 0.91 \mathrm{Mn} ; 0.18 \mathrm{Ni} ; 0.16 \mathrm{Cr} ; 0.017 \mathrm{~S}$;

$0.010 \mathrm{P}$ (structural carbon steel 65G [7]).

\section{Experimental procedures}

HAZ overheated zone has limited dimensions, and its width does not exceed $0.5 \mathrm{~mm}$. Therefore, investigations were conducted on model samples, which were treated by thermal cycle of welding (TCW). $100 \times 20 \times 10 \mathrm{~mm}$ samples with $7 \mathrm{~mm}$ deep notch in the center were used. For TCW simulation the samples wee heated by passing current up to the temperature of $1250^{\circ} \mathrm{C}$ (heating rate of $150^{\circ} \mathrm{C} / \mathrm{s}$ ), and then were cooled by a preset program. Rate of sample cooling in the temperature range of $600-500^{\circ} \mathrm{C}(\mathrm{W} 6 / 5)$ was selected from the condition of formation of characteristic structures in the metal. For wheel steel of grade 2 the following values of cooling rate were taken: $\mathrm{W} 6 / 5=6^{\circ} \mathrm{C} / \mathrm{s}$ (bainitic structure), $13,5^{\circ} \mathrm{C} / \mathrm{s}$ (bainiticmartensitic structure) and $20^{\circ} \mathrm{C} / \mathrm{s}$ (martensitic-bainitic structure). Investigations on steel $65 \mathrm{G}$ were performed at cooling rates of $6^{\circ} \mathrm{C} / \mathrm{s}$ and $13,5^{\circ} \mathrm{C} / \mathrm{s}$, when bainitic-martensitic and martensitic structures are formed in the metal of HAZ overheated zone.

Then, $3 \mathrm{~mm}$ deep fatigue crack was grown from the sample notch tip at cyclic loading (cycle stress of 120 $\mathrm{MPa}$, frequency of $35 \mathrm{~Hz}$ ). After that samples with the fatigue crack were tested by static loading at threepoint bending with loading rate of $1 \mathrm{~mm}$ per minute. Testing was performed by standard fracture mechanics procedure, and stress intensity factor $\mathrm{K} 1 \mathrm{C}$ was taken as the criterion for evaluation of HAZ metal resistibility to brittle fracture.

Saturation by diffusible hydrogen ([H]dif) of samples with a fatigue crack was performed by electrolytic procedure directly before their static loading. Used for this purpose was electrolytic solution of sulphuric acid ( $\mathrm{H} 2 \mathrm{SO} 4)$ in distilled water with addition of sodium thiosulphate (Na2S2O2) in the proportion of 0,05 g per 1 liter at $10 \mathrm{~A} / \mathrm{sm} 2$ current density. [H]dif quantity was varied from 0,2 to $1,5 \mathrm{ml}$ per $100 \mathrm{~g}$ of metal by varying the duration of sample soaking in electrolytic solution. We proceeded from the results of [11], which showed that diffusible hydrogen content in the HAZ can reach $1,5 \mathrm{ml} / 100 \mathrm{~g}$ at its initial amount in the deposited metal of up to $10 \mathrm{ml} / 100 \mathrm{~g}$.

Meal structure was studied by optical microscopy method. Sample fractures after testing were examined by scanning electron microscopy methods in SEM-515 microscope of Philips company, fitted with energy dispersion spectrometer of LINK system.

\section{Investigation results and their discussion}

Generalized results of investigation of diffusible hydrogen influence on fracture toughness of HAZ metal in high-strength carbon steels at static loading are given in Figures 1 and 2.

$\mathrm{K} 1 \mathrm{C}, \mathrm{M} \Pi \mathrm{a} \mathrm{M}$

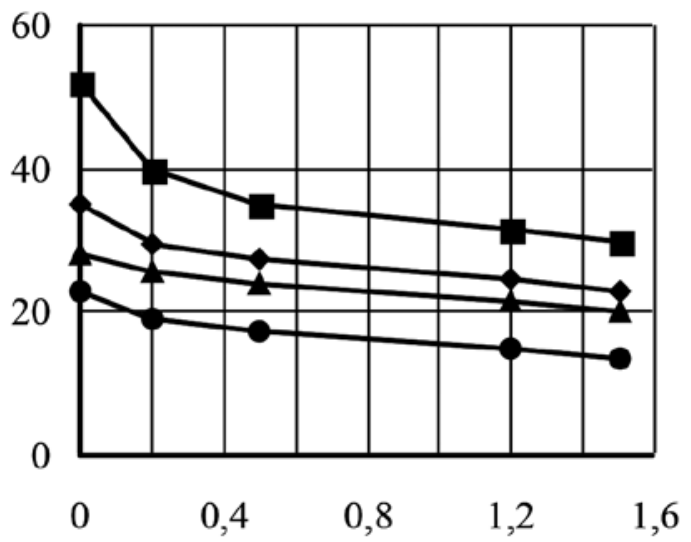

Fig. 1. [H]dif influence on resistibility to brittle fracture of grade 2 wheel steel: 1 - grade 2 wheel steel; 2 - HAZ metal, cooling rate $W 6 / 5=20^{\circ} \mathrm{C} / \mathrm{s} ; 3-13,5^{\circ} \mathrm{C} / \mathrm{s} ; 4-6^{\circ} \mathrm{C} / \mathrm{s}$ 
К1C, МПаУм

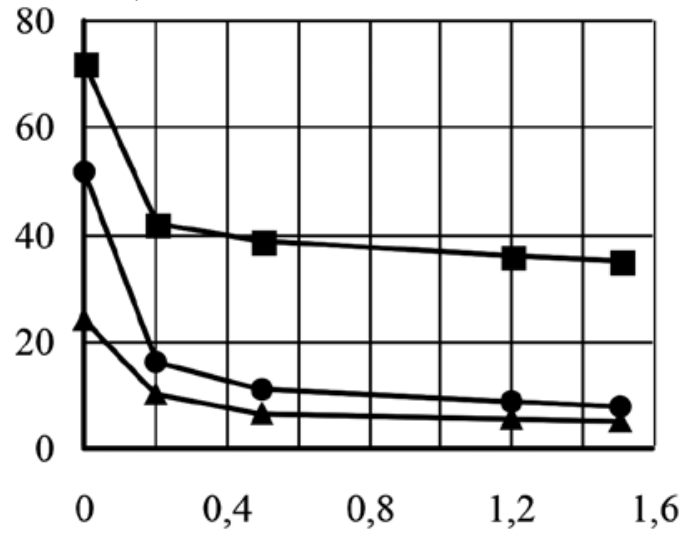

Fig. 2. $[\mathrm{H}]$ dif influence on resistibility to brittle fracture of $65 \mathrm{G}$ steel: 1 - $65 \mathrm{G}$ steel; 2 - HAZ metal, cooling rate $\mathrm{W} 6 / 5=6^{\circ} \mathrm{C} / \mathrm{s} ; 3-13,5^{\circ} \mathrm{C} / \mathrm{s}$

As is seen from the presented data, resistibility to brittle fracture of high-strength carbon metal essentially depends on diffusible hydrogen content. Depending on carbon content in the metal, stress intensity factor KIC changes in different ways at fracture. For wheel steel of grade $2(0,58 \% \mathrm{C})$ not exposed to TCW, presence of diffusible hydrogen on the level of $0,2 \mathrm{ml} / 100 \mathrm{~g}$ in the metal, leads to lowering of $\mathrm{K} 1 \mathrm{C}$ value by $23 \%$ (from 52 to $40 \mathrm{MPa} / \mathrm{m}$ ). At subsequent increase of [H]dif to $1.5 \mathrm{ml} / 100 \mathrm{~g}$ in the metal, stress intensity factor decreases to $30 \mathrm{MPa} \sqrt{\mathrm{m}}$. Thus, wheel steel resistibility to crack propagation in the presence of diffusible hydrogen content in the metal, decreases by approximately 1,7 times. More marked embrittlement in the presence of hydrogen takes place in the metal, in which carbon content is higher and is equal to $0,65 \%$. At minimum saturation of $65 \mathrm{G}$ steel by diffusible hydrogen, $\mathrm{K} 1 \mathrm{C}$ value decreases to $42 \%$ (from 72 to $42 \mathrm{MPa} \sqrt{\mathrm{m}}$ ), and at its maximum content - by 2,1 times (to $35 \mathrm{MPa} / \mathrm{m}$ ).

It should be also noted that stress intensity factors of grade 2 wheel steel and $65 \mathrm{G}$ steel in their initial condition are different. This difference is related to the conditions of metal production and cutting out samples for investigations. Samples from steel 65G were cut out of rolled sheets, and those from wheel steel of grade 2 - after thermal processing of solid-rolled wheel tread after long service period.

In order to clarify the properties of HAZ metal of high-strength carbon steels, it is necessary to first consider their structural state, which formed under the impact of TCW.

Structure of grade 2 wheel steel, which was not exposed to TCW impact, is represented by pearlite-ferrite mixture (Fig.3, a), grain size is $16-32 \mu \mathrm{m}$ and structural component microhardness is HV0.1 = 1990...2450 MPa, whereas total integral metal hardness is HV10 = $2300 \mathrm{M}$ Па. Ferrite fringes of $5-10$ $\mu \mathrm{m}$ size are located along grain boundaries. Under the conditions of welding, when cooling rate is $6^{\circ} \mathrm{C} / \mathrm{s}$, upper bainite structure with greater grain size (63...94 $\mu \mathrm{m})$ and microhardness of 2640-3090 MPa forms in the HAZ metal overheated zone (Fig.3, b). Integral hardness of metal with such a structure is equal to $3140 \mathrm{MPa}$. It is known that upper bainite forming by diffusion mechanism, unlike other metal structures, has low ductility [12]. Therefore, resistibility of such metal to brittle fracture drops abruptly even in the absence of diffusible hydrogen. $\mathrm{K} 1 \mathrm{C}$ value deceases by 2,3 times (from 52 to $23 \mathrm{MPa} \sqrt{\mathrm{m}}$ ).

At cooling rate of $13,5^{\circ} \mathrm{C} / \mathrm{s} \mathrm{HAZ}$ overheated zone metal forms bainitic-martensitic structure with prevailing fraction of lower bainite (80\%) with structural component microhardness on the level of $3340-4320$ MPa (Fig.3, c), and integral metal hardness of 3520 $\mathrm{MPa}$. Metal resistibility to brittle fracture rises compared to the conditions of cooling at $6^{\circ} \mathrm{C} / \mathrm{s}$, by $22 \%$ (up to $28 \mathrm{MPa} / \mathrm{m})$. At $\mathrm{W} 6 / 5=20^{\circ} \mathrm{C} / \mathrm{s} \mathrm{HAZ}$ overheated zone forms a structure with approximately equal quantity of martensite and lower bainite (46\% / 54\%), structural component microhardness rises up to $3780-4560 \mathrm{MPa}$ (integral value of $3920 \mathrm{MPa}$ ), and grain size is equal to $32 \ldots 47,5 \mu \mathrm{m}$ (Fig.3, d). Metal of HAZ overheated zone with such a structure has the highest resistibility to brittle fracture, with coefficient $\mathrm{K} 1 \mathrm{C}=35 \mathrm{MPa} / \mathrm{m}$.
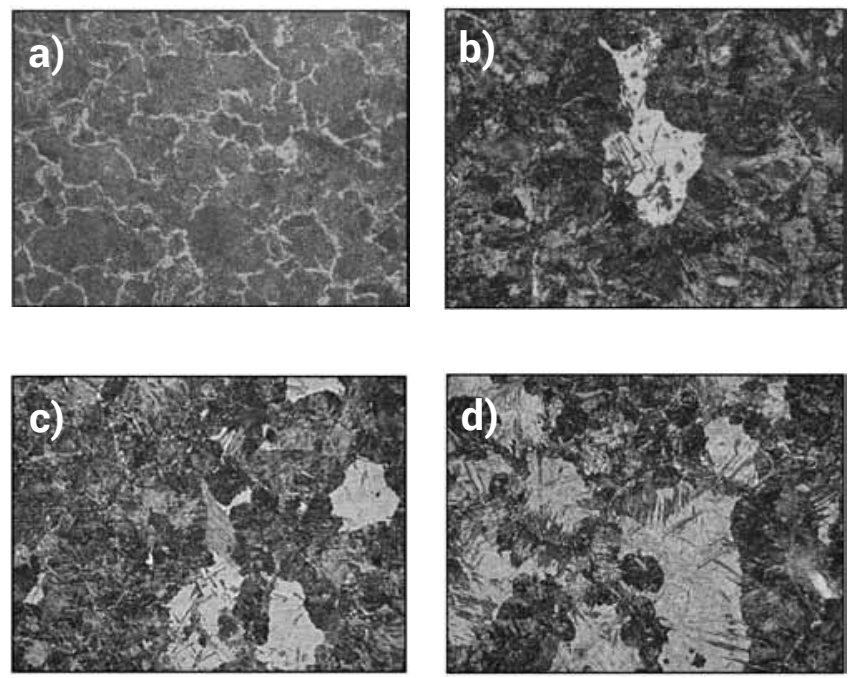

Fig. 3. Microstructure of grade 2 wheel steel $(\times 500$, reduced 2 times): a - grade 2 wheel steel; b - HAZ metal, cooling rate W6 $/ 5=6^{\circ} \mathrm{C} / \mathrm{s} ; \mathrm{c}-13,5^{\circ} \mathrm{C} / \mathrm{s} ; \mathrm{d}-20^{\circ} \mathrm{C} / \mathrm{s}$

Structure of $65 \mathrm{G}$ structural steel, which was not exposed to TCW impact, is represented by bainite (Fig.4, a), with grain size of $16 . .24 \mu \mathrm{m}$ and microhardness of $2570 . . .2730 \mathrm{MPa}$. Integral hardness of weld metal is $2760 \mathrm{MPa}$. In the HAZ overheated zone metal quenching processes proceed and grains become coarser under TCW impact. Unlike wheel steel of grade 2, at the rate $\mathrm{W} 6 / 5=6^{\circ} \mathrm{C} / \mathrm{s} 65 \mathrm{G}$ steel forms bainitic-martensitic structure with $70 \% / 30 \%$ ratio of structural components (Fig.4, b). Lower bainite microhardness is $3220-3800 \mathrm{MPa}$, that of martensite is $5600-6130$ $\mathrm{MPa}$, and metal integral hardness is $4570 \mathrm{MPa}$. Grain 
size is up to $63 \ldots 94 \mu \mathrm{m}$. At increase of cooling rate up to $13,5^{\circ} \mathrm{C} / \mathrm{S}$ the metal mainly forms martensitic structure (98\%) with more than $6130 \mathrm{MPa}$ martensite microhardness and metal integral hardness on the level of $7200 \mathrm{MPa}$ (Fig.4, c). Lower bainite was also found in the structure in the amount of approximately $2 \%$, which is located along grain boundaries. Grain size is the same as at lower cooling rate. Metal resistibility to brittle fracture changes accordingly. Under the conditions of formation of more ductile bainitic-martensitic structure $\left(6^{\circ} \mathrm{C} / \mathrm{s}\right) \mathrm{K} 1 \mathrm{C}$ for HAZ metal decreases by $28 \%$ (from 72 to $52 \mathrm{MPa} \sqrt{\mathrm{m}}$ ). At formation of a less ductile martensitic structure $\left(13,5^{\circ} \mathrm{C} / \mathrm{s}\right)$ metal resistibility to brittle facture deceases by almost 3 times.

a)

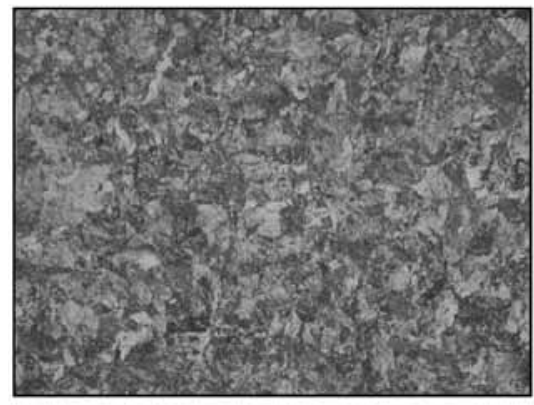

b)

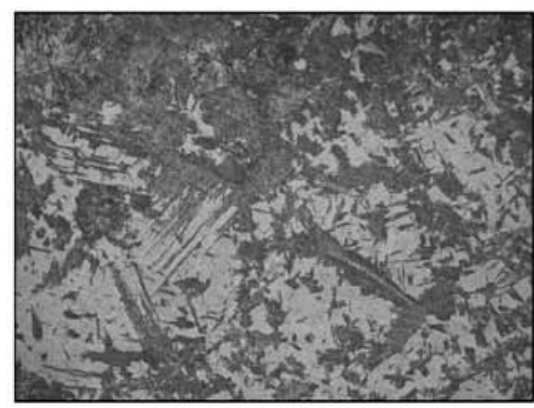

c)

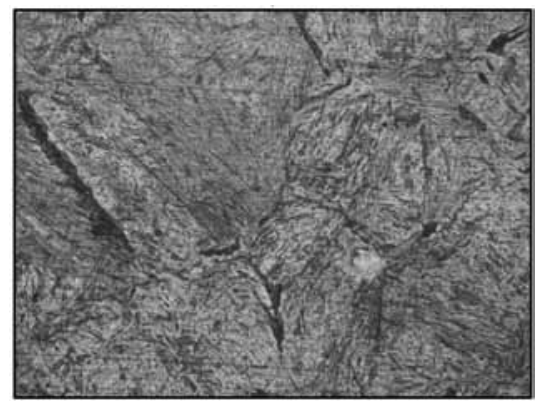

Fig. 4. Microstructure of $65 \mathrm{G}$ steel (reduced 2 times): $\mathrm{a}-65 \mathrm{G}$ steel; b $-\mathrm{HAZ}$ overheated zone, cooling rate $\mathrm{W} 6 / 5=6^{\circ} \mathrm{C} / \mathrm{s} ; \mathrm{c}-13,5^{\circ} \mathrm{C} / \mathrm{s}$

Comparing the above test results it can be stated that high-carbon metal, in which bainitic-martensitic structure formed under TCW impact, at more than 1 ratio of bainite and martensite, has relatively higher resistivity to brittle fracture. At formation of prevailing structure of upper bainite or martensite of higher hardness in the HAZ, metal resistivity to brittle fracture rises abruptly.
At saturation of high-strength carbon steels by diffusible hydrogen resistibility of HAZ metal to brittle fracture, which even initially is not high, decreases. Level of this lowering depends on carbon content, which determines the degree of metal quenching under TCW impact. More abrupt changes of properties are characteristic for HAZ metal of $65 \mathrm{G}$ steel: presence of diffusible hydrogen in it on the level of $0,2 \mathrm{ml} / 100 \mathrm{~g}$ leads to lowering of $\mathrm{K} 1 \mathrm{C}$ value by $2,4-3,2$ times, and for HAZ metal of grade 2 wheel steel - by 1,1-1,2 times. At subsequent increase of $[\mathrm{H}]$ dif in the metal up to $1,5 \mathrm{ml} / 100 \mathrm{~g}$, stress intensity factor decreases gradually up to 2 times for HAZ of $65 \mathrm{G}$ steel, and by $40 \%$ for grade 2 wheel steel. Compared to HAZ metal which was not subjected to hydrogenation, presence of diffusible hydrogen in the structure lowers its resistibility to brittle fracture by 5-7 times for $65 \Gamma$ steel, and by 1,3 times for grade 2 wheel steel.

At examination of sample fractures by scanning electron microscopy methods, characteristic fracture zones and their features were established, depending on structural condition on the metal and its diffusible hydrogen content. Fracture consists of 3 characteristic zones (Fig.5):

zone I - region of initiation and propagation of a fatigue crack, formed as a result of cyclic loading; zone II - region of main crack propagation at static loading by bending ;

zone III - region of final fracture.

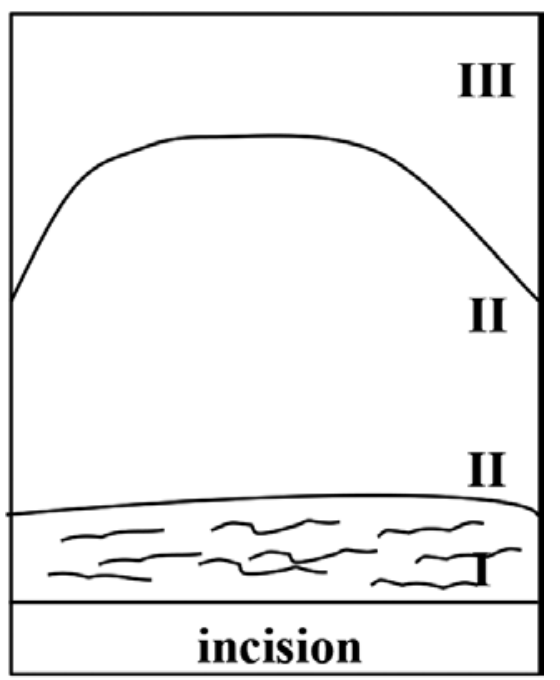

Fig. 5. Characteristic zones of fracture of standards after tests: I fatigue crack; II - main crack; III - zone of final fracture

Initiation of a fatigue crack in HAZ metal of highcarbon steel, irrespective of its structural state, proceeds in brittle mode along grain boundaries (Fig.6, a, b). Fatigue crack also propagates in brittle mode, but predominantly through grain body (Fig.6, c, d). The features of fatigue crack propagation, depending on steel composition and metal structural condition, are as follows. In HAZ metal of grade 2 wheel steel with ba- 
initic structure $\left(\mathrm{W}_{6 / 5}=6^{\circ} \mathrm{C} / \mathrm{s}\right)$ the size of brittle fracture facets is $30 . .100 \mu \mathrm{m}$, and that of bainitic-martensitic structure $\left(13,5^{\circ} \mathrm{C} / \mathrm{s}\right)$ is $30 \ldots .70 \mu \mathrm{m}$. This fracture zone is characterized by presence of secondary cracks along grain boundaries. In wheel steel with upper bainite structure the size of these cracks is $50 . .100 \mu \mathrm{m}$, and at formation of lower bainite and martensite structure in the HAZ, their extent is smaller (up to $60 \mu \mathrm{m}$ ). Facet dimensions are similar also on fractures of $65 \mathrm{G}$ steel at these cooling rates. Now, secondary cracks have the length of up to $200 \mu \mathrm{m}$ at $\mathrm{W}_{6 / 5}=13.5^{\circ} \mathrm{C} / \mathrm{s}$.

In the zone of propagation of main crack, which
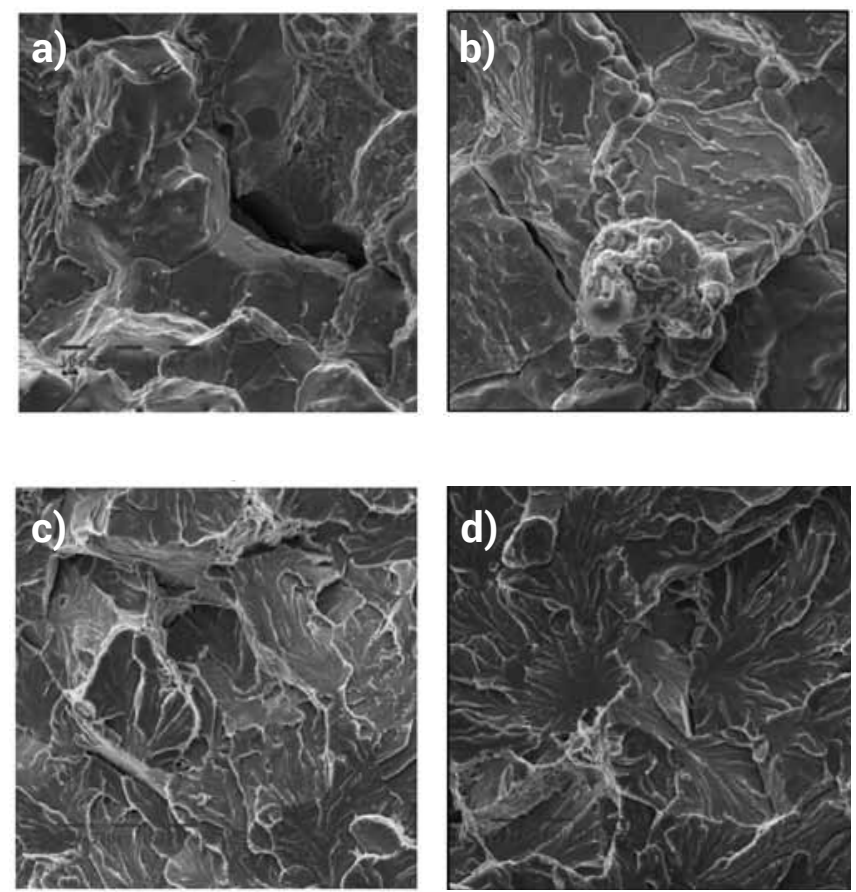

Fig. 6. Fracture surface of HAZ metal of grade 2 wheel steel in the zone of fatigue crack initiation $(a, b)$ and propagation $(c, d)(\times 1010$, reduced 2 times): $\mathrm{a}, \mathrm{b}-\mathrm{W}_{6 / 5}=6^{\circ} \mathrm{C} / \mathrm{s}, \mathrm{c}, \mathrm{d}-13,5^{\circ} \mathrm{C} / \mathrm{s}$
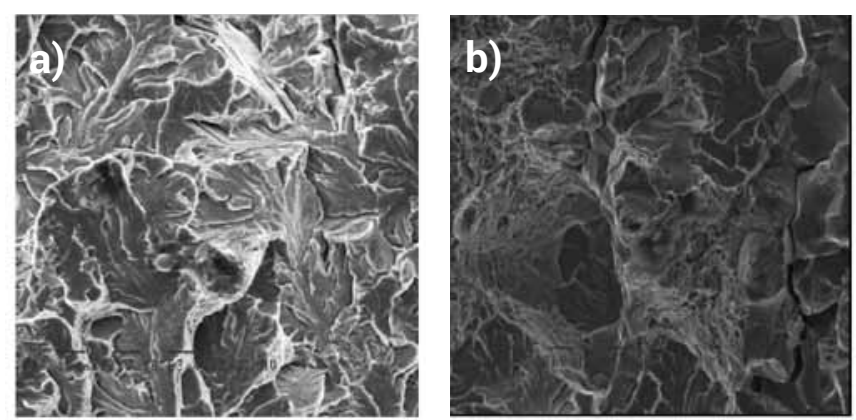

Fig. 7. Fracture of $\mathrm{HAZ}$ metal of $65 \mathrm{G}$ steel $\left(\mathrm{W} 6 / 5=13,5^{\circ} \mathrm{C} / \mathrm{s}\right)$ in the zone of main crack development ( $\times 1010$, reduced 2 times)

developed under static loading in the HAZ metal of grade 2 wheel steel, fracture is brittle intragranular one (BIG), corresponding to the structure given in Fig.6, c, d. At cooling rate of $6^{\circ} \mathrm{C} / \mathrm{s}$ secondary cracks of length up to $\mathrm{LS}=40 \mu \mathrm{m}$ are found, and at $13,5^{\circ} \mathrm{C} / \mathrm{s}$ their length is less than $5 \mu \mathrm{m}$. In this fracture zone of HAZ metal of $65 \mathrm{G}$ steel fracture runs in brittle mode both along the boundaries (BMZ), and through grain body, with up to $60 \mu \mathrm{m}$ long secondary cracks (Fig.7). In final fracture zone fracture proceeds in ductile mode for all the samples

At diffusible hydrogen saturation, mode of sample fracture in the zone of main crack development changes, and brittle fracture regions appear in final fracture zone, its fraction being equal up to $30 \%$. Generalized results of fracture examination are given in Table 1.

At saturation of HAZ metal of high-strength carbon steels by diffusible hydrogen the fraction of brittle intergranular fracture in sample fractures rises significantly. Particularly abrupt changes of fracture structure are characteristic for $65 \mathrm{G}$ steel. At cooling rate of $6^{\circ} \mathrm{C} / \mathrm{s}$, when $\mathrm{HAZ}$ metal forms bainitic-martensitic structure $(70 / 30)$, presence of $[H]$ dif at the level of 0,2

Table I. Characterization of HAZ metal fracture of studied steels in main crack propagation zone

\begin{tabular}{|c|c|c|c|c|c|c|c|c|}
\hline \multirow{2}{*}{$\begin{array}{c}\text { [H]dif, } \\
\mathrm{mI} / 100 \mathrm{~g}\end{array}$} & \multicolumn{4}{|c|}{ Grade 2 wheel steel } & \multicolumn{4}{c|}{$65 \mathrm{G}$ steel } \\
\cline { 2 - 9 } & \multicolumn{2}{|c|}{$6^{\circ} \mathrm{C} / \mathrm{s}$} & \multicolumn{2}{|c|}{$13,5^{\circ} \mathrm{C} / \mathrm{s}$} & \multicolumn{2}{c|}{$6^{\circ} \mathrm{C} / \mathrm{s}$} & \multicolumn{2}{c|}{$13,5^{\circ} \mathrm{C} / \mathrm{s}$} \\
\cline { 2 - 9 } & $\frac{\mathrm{BIG}, \%}{\mathrm{~L}^{\prime}, \mu \mathrm{m}}$ & $\frac{\mathrm{BMZ},}{\mathrm{L}_{\mathrm{s}^{\prime}} \mu \mathrm{m}}$ & $\frac{\mathrm{BIG} \%}{\mathrm{~L}_{\mathrm{s}^{\prime}} \mu \mathrm{m}}$ & $\frac{\mathrm{BMZ}, \%}{\mathrm{~L}_{\mathrm{s}^{\prime}} \mu \mathrm{m}}$ & $\frac{\mathrm{BIG} \%}{\mathrm{~L}_{\mathrm{s}^{\prime}} \mu \mathrm{m}}$ & $\frac{\mathrm{BMZ}, \%}{\mathrm{~L}_{\mathrm{s}^{\prime}} \mu \mathrm{m}}$ & $\frac{\mathrm{BIG} \%}{\mathrm{~L}_{\mathrm{s}^{\prime},} \mu \mathrm{m}}$ & $\frac{\mathrm{BMZ}, \%}{\mathrm{~L}_{\mathrm{s}^{\prime}} \mu \mathrm{m}}$ \\
\hline 0 & $\frac{100}{40}$ & - & $\frac{100}{5}$ & - & $\frac{95}{30}$ & $\frac{5}{30}$ & $\frac{80}{60}$ & $\frac{20}{60}$ \\
\hline 0,2 & $\frac{80}{100}$ & $\frac{20}{100}$ & $\frac{70}{40}$ & $\frac{30}{40}$ & $\frac{50}{150}$ & $\frac{50}{150}$ & $\frac{30}{220}$ & $\frac{70}{220}$ \\
\hline 0,5 & $\frac{70}{120}$ & $\frac{30}{120}$ & $\frac{65}{60}$ & $\frac{35}{60}$ & $\frac{40}{170}$ & $\frac{60}{170}$ & $\frac{20}{250}$ & $\frac{80}{250}$ \\
\hline
\end{tabular}


$\mathrm{ml} / 100 \mathrm{~g}$, increases the fraction of brittle intergranular facture to $50 \%$. Here, $\mathrm{K} 1 \mathrm{C}$ value deceases 3,2 times. Increase of BMZ fraction in the presence of hydrogen in the metal, is also characteristic for wheel steel, but as a result formation of more ductile structures resistibility to brittle fracture deceases by $20 \%$. Secondary crack length is one of fracture characteristics. As is seen, with increase of diffusible hydrogen content, extent of secondary cracks in HAZ metal increases: 3 times for wheel steel, and more than 3,5 - 6 times for $65 \mathrm{G}$ steel. Typical sample fractures at HAZ metal saturation by diffusible hydrogen are given in Fig.8.

Conducted investigations showed that in welding and surfacing of high-strength carbon steels, it is necessary to ensure not just the conditions of cooling, under which relatively ductile bainitic-martensitic
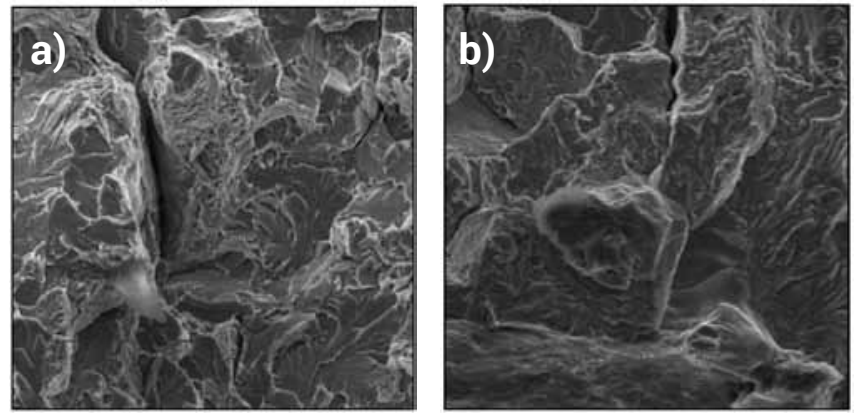

Fig. 8. Fracture of $65 \mathrm{G}$ steel $\mathrm{HAZ}$ metal $\left(\mathrm{W} 6 / 5=13,5^{\circ} \mathrm{C} / \mathrm{s}\right)$ in main crack propagation zone at saturation by diffusible hydrogen at the level of $0,2 \mathrm{ml} / 100 \mathrm{~g} \mathrm{(a)}$ and $0,5 \mathrm{ml} / 100 \mathrm{~g}(\mathrm{~b}),(\times 1010$, reduced 2 times) structure with more than 1 ratio of components forms in the metal of HAZ overheated zone, but also lower content of diffusible hydrogen (below $0,2 \mathrm{ml} / 100 \mathrm{~g}$ ). With increase of carbon content in steel, requirements to lowering diffusible hydrogen content in HAZ metal are increased. As shown in [13], depending on welding consumable humidity, diffusible hydrogen content in the deposited metal in gas-shielded solid wire welding can be up to $3,0 \mathrm{ml} / 100 \mathrm{~g}$, in manual-arc welding it can be $12,0 \mathrm{ml} / 100 \mathrm{~g}$, and in submerged-arc welding $-8,0 \mathrm{ml} / 100 \mathrm{~g}$. Considering that diffusible hydrogen content in HAZ metal is approximately 7 times lower [11], it is obviously highly problematic to ensure high resistivity to brittle fracture of welded joints of high-strength carbon steels. This requires application of special welding processes, in which hydrogen saturation of deposited metal is minimum, or techniques, allowing removal of diffusible hydrogen after weIding. Gas-shielded flux-cored wire welding can be regarded as one of the special processes, application of which enables ensuring diffusible hydrogen content in the deposited metal in the range of $0,3-1,3 \mathrm{ml} / 100 \mathrm{~g}$ [13].

Note that today in railway enterprises of CIS countries the technological operation of delayed cooling after surfacing is applied to prevent item cracking at reconditioning of freight car wheels by surfacing. A similar technological operation is also envisaged in arc welding of rails. During delayed cooling of items, which runs for 3-5 hours, diffusible hydrogen is removed from the metal, and the items feature an increased resistance to cracking in service.

\section{Conclusions}

High-strength carbon steels have a high susceptibility to embrittlement in the presence of hydrogen. With increase of diffusible hydrogen content, metal resistibility to brittle fracture decreases. For wheel steel of grade 2, carbon content in which is $0,58 \%$, increase of $[\mathrm{H}]$ dif in the metal up to $1,5 \mathrm{ml} / 100 \mathrm{~g} \mathrm{le}$ ads to lowering of stress intensity factor by 1,7 times at crack propagation. A more abrupt embrittlement in hydrogen presence occurs in the metal with $0,65 \%$ carbon content. Brittle fracture resistibility of such metal decreases by 2,1 times.

During welding of high-strength carbon steel joints, quenching structure in different states forms in HAZ overheated zone, depending on carbon content in the metal and its cooling rate. To achieve a comparatively high resistance of joints to crack propagation, it is necessary to ensure formation of bainitic-martensitic structure in HAZ metal, the component ratio in which is more than 1 .

At saturation of HAZ metal of high-strength carbon steels by diffusible hydrogen, their susceptibility to brittle fracture becomes higher. To lower metal embrittlement, it is necessary to apply special welding techniques, in which hydrogen saturation of deposited metal is minimum (less than $0,2 \mathrm{ml} / 100 \mathrm{~g}$ ), or techniques allowing removal of diffusible hydrogen from the metal after welding. 


\section{References}

[1] Kasatkin 0.G. Features of hydrogen embrittlement of highstrength steels in welding // Automatic welding. - 1994. No.1. - P.3-7.

[2] Shvachko I.V., Ignatenko A.V. Model of hydrogen transportation by dislocations. //Automatic welding. -2007 . - No.2. - P.27-30.

[3] Dislocation model of hydrogen localizing of ductility in metals with BCC lattice / A.V.Ignatenko, I.K.Pokhodnya, A.P.Paltsevich, V.S.Sinyuk // Automatic Welding. - 2012. - No.3. - P.22-27.

[4] Influence of thermodeformational cycle of surfacing on structure and properties of higher strength railway wheels at their reconditioning / A.A.Gaivoronskiy, V.D.Pozdnyakov, V.A.Sarzhevskii, V.G.Vasilyev, V.Yu.Orlovskiy // Automatic welding. 2010. - No.5. - P.22-26.

[5] Influence of deposited metal composition on structure and mechanical properties of reconditioned railway wheels / A.A.Gaivoronskiy, V.D.Pozdnyakov, L.I.Markashova etc. // Automatic welding. -2012 . - No.8. - P.18-24.
[6] DSTU GOST 10791 Whole-rolled wheels. Technical conditions.

[7] GOST 1050 High-quality structural carbon steel.

[8] New methods of evaluation of metal resistivity to brittle fracture / Ed. by Yu.N.Robotnov. - M.: Mir, 1972. - 439 p.

[9] Shorshorov M.Kh, Chernyshova T.A., Krasovskiy A.I. Metal testing for weldability. - M.: Metallurgia, 1972. - 240p.

[10] GOST 25.506 Methods of mechanical testing of metals. Determination of characteristics of crack resistance (fracture toughness) at static loading.

[11] Makhnenko V.I., Koroleva T.V., Lavrinets I.G. Influence of microstructural changes on hydrogen redistribution in fusion welding of structural steels // Automatic welding. - 2002. No.2. - P.7-13.

[12] Grabin V.F., Denisenko A.V. Metals science of welding low- and medium-alloyed steels. - K.: Naukova Dumka, 1978. - 272p.

[13] Gaivoronskiy A.A. Influence of diffusible hydrogen on resistivity to delayed fracture of high-carbon steel welded joints // Automatic welding. -2013 . - No.5. - P.15-21.

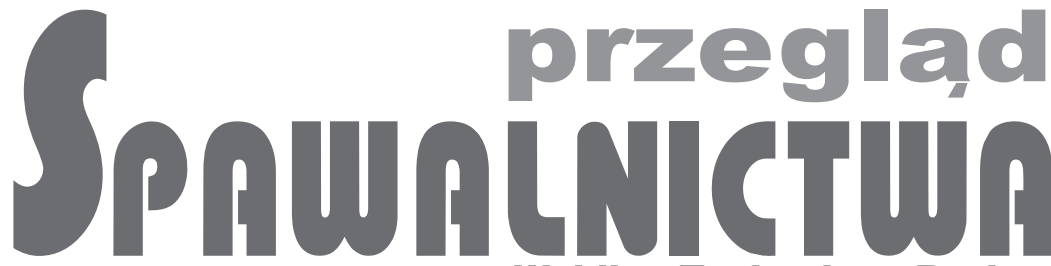

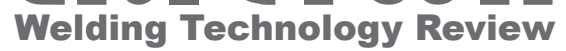

\section{PRÓBA KAMANIA ZŁĄCZY SPAWANYCH ATLAS PRZEKOMÓW JACEK SŁANIA KRZYSZTOF STANISZEWSKI}

Cena 1 egzemplarza książki:

Próba łamania złączy spawanych

Atlas przełomów wynosi:

$60 \mathrm{zł} \mathrm{(w} \mathrm{tym} \mathrm{5 \%} \mathrm{VAT)}$

\section{W celu zamówienia książki w Redakcji należy wypełnić formularz zamieszczony obok i przesłać go w formie faksu, skanu lub listu na adres:}

REDAKCJA - Przegląd Spawalnictwa AW SIMP ul. Świętokrzyska 14a, 00-050 Warszawa tel.: 2282725 42, faks: 223361479 e-mail: redakcja@pspaw.pl

Wpłaty należy dokonać na rachunek bankowy: Bank BPH S.A. Oddział w Warszawie 45106000760000320000431836

\section{Zamawiam książkę:}

Próba łamania łączy spawanych Atlas przełomów w Redakcji Przegląd Spawalnictwa w liczbie .... egz.

Imię i nazwisko

\section{Firma}

Adres

NIP

Kontakt do osoby zamawiającej:

Oświadczam, że jestem podatnikiem VAT i upoważniam firmę do wystawienia faktury bez podpisu Podpis 